\title{
Policy Strategy for Halal Logistics Development in Indonesia
}

\author{
Sutandi ${ }^{1}$ \\ \{sutandi@stiami.ac.id ${ }^{1}$ \} \\ Department Logistics Management, Institut Ilmu Sosial dan Manajemen Stiami ${ }^{1}$
}

\begin{abstract}
The current global economic trend is the halal industry which is characterized by a rapidly growing food industry involving a complex global market. In 2017, Indonesia was included in the top 10 countries with the largest halal industry consumers in the world based on Global Islamic Economy Indicator data. The Indonesian halal industry is still struggling with halal product certification but has not paid attention to the movement of goods to customers by paying attention to the transparency of raw material sources and contamination of halal products for Muslim residents and there are no guidelines for all parties in developing halal logistics in Indonesia. So, this study aims to map the strategy for the development of the halal logistics industry in Indonesia using a road mapping model. In formulating a strategy for government policies and facilities in supporting halal logistics, it refers to the six main drivers in the Indonesian National Logistics System Blueprint. The results of this study are a strategic roadmap for developing policies for the halal logistics industry in Indonesia from the aspects of commodities, infrastructure, business actors, human resource competence, information and communication technology, as well as regulations and policies, which are expected to contribute as draft recommendations for the government in policy making.
\end{abstract}

Keywords: Policy Strategy, Halal Logistics, Road-Mapping Model.

\section{Introduction}

The current attractive global economic trend is related to the halal industry including halal tourism. In 2017 Indonesia was included in the top 10 countries as the largest halal industry consumers in the world based on Global Islamic Economy Indicator data. Indonesia is ranked number one in the world for halal food shopping and is ranked fifth in the halal tourism sector. In addition, Indonesia ranked sixth for pharmaceuticals and halal cosmetics ranked sixth and tenth for Islamic finance.

Besides food, which is included in halal products include pharmaceuticals, cosmetics, clothing, financial services, and logistics (Tieman, 2010). Regarding logistics, the amount of the halal logistics market is US \$ 2.3 trillion with the largest distribution in Southeast Asia, the 
Middle East and Africa (Abdullah, 2015). This value is three times the GDP of Indonesia or equivalent to IDR 30,000 trillion or. The growth trend of the Muslim population is around $1.86 \%$ per year, the value of the halal logistics market is very lucrative (Martono, 2016).

The management of halal supply chain performance in Indonesia must refer to the Effective principle (addressing process quality and minimizing waste), Efficient (low cost and high utilization of existing assets) and robust (high availability of halal assets). So that this becomes a new strength and business opportunity in Indonesia. This is indicated by the increased demand for halal products (food and non-food) by Muslim communities.

While in Indonesia itself (a Muslim majority country) there are still not many logistic service providers certified as "halal logistics". The government needs to support logistical actors in Indonesia to implement and obtain "halal logistics" certification so they can control the supply chain of halal products in Indonesia and the world.

The success of a public policy is determined by good policy planning. One of them is by compiling a master plan or roadmap. Literally, a roadmap can be interpreted as a map of determinants or directions. In the context of efforts to achieve the results of an activity, a roadmap is a document planning and implementing programs and activities within a certain range. Therefore, in developing the halal industry sector in Indonesia, especially halal logitik requires a roadmap in ensuring the success of halal logistics development policies.

\section{Problems}

How to determine the strategy for halal logistics development policies in Indonesia?

\section{Literature Study}

In general, logistics is defined as the process of planning, implementing and controlling efficiently, effective flow and storage of goods, services and information from the beginning to the final destination to serve the needs of consumers. The purpose of logistics is to ensure that customers can consume the product at the right time, the right amount and in good condition. Therefore, logistics management involves a series of activities including transportation, storage and warehousing, inventory management, material management, product scheduling and customer service. Logistics plays a key role in protecting product quality and conditions through proper transportation, storage and handling in the supply chain, until it reaches its final destination (Tieman, 2008).

The success of the halal industry depends on the management capabilities of logistics services in ensuring the integrity of halal products from start to finish for consumption. Kamaruddin et al (2012) mention the trend of consumer consumption not only for halal products but also halal logistics. Tieman (2011) reiterates the distribution, storage, handling and procurement of halal products must follow Sharia principles to be considered halal. Therefore, halal and Sharia logistic competencies including technical knowledge are very important to maintain the integrity of halal products.

In halal logistics, halal products must be protected from non-halal products or substances until they arrive at their final destination. However, there is a high tendency for halal products to cross contamination during the process and give due to transportation or contaminated containers (Zulfakar et al. 2014).

Halalan-toyyiban can literally be translated as "halal and good" in the clear sense of the process of handling, production and material / composition. The basic principles of halal 
logistics are separation (from raw materials, products or accessories that are not halal) both in the process of handling, producing, storing, labeling, transporting, delivering and other work processes included in the supply-chain process from the initial producers (ultimate producers ) reaching the ultimate consumers.

Halal logistics focuses on the handling and physical movement of goods so that there is a similarity between the Standard Food Safety (ISO 22000 certification) and the Halal Food Standard with derivatives of Halal Logistics Standards. The difference is that the scope of the Food Safety system is to ensure that food is safe when consumed by humans (to ensure that food is safe at the time of human consumption). While the Halal Standard Food system is applied to the food / related and non-food products, covering various processes involved in their production, including appliances and materials used, storage, preparation, packaging, distribution, sale and display.

Halal Logistics Benchmarking refers to Malaysia and Japan. The Malaysian Halal Industry has a master plan (2008-2020) which has a focus on four areas, namely Specialty Processed Food, Cosmetic Personal Care, Ingredients, and Animal Husbandary with key driving forces are legalization and policy frameworks, human resources, physical infrastructure and connectivity, funding and incentives, industry standards and certification, and delivery systems in the public sector.

Japan has seen a big opportunity for the halal industry that requires halal labels on their products. Halal labels are obtained by applying Halal certification. In Japan halal certification is carried out by an institution called Nippon Asia Halal Association (NAHA). Applications in Japan are carried out according to Halal standards such as ISO (International Standard Organitation), HACCP (Hazard Analysis Critical Control Points), or GMP (Good Manifacturing Practice). With this institution, it can be ascertained that in the future more Japanese halal products will enter the Muslim market in the World

The main key to the halal industry is the existence of halal certification. Based on Law Number 33 of 2014 concerning Halal Product Guarantee (JPH), mandates the establishment of Halal Product Guarantee Management Agency (BPJPH) no later than 2017 or three years after the law is passed. This institution began operations in early 2018. The parties involved in the halal certification process are BPJPH, MUI, and Halal Inspection Institutions (LPH).

The challenge of implementing halal logistics is halal facilities. Halal supply chain facilities are very important along with adherence to religious guidelines regarding halal products. However, the implementation will lead to additional cost logistics related to production, storage and distribution in addition to process costs because halal facilities require halal audits of the network of facilities used. As a result, the price of halal food will be expensive. Therefore, it is necessary to identify halal supply chain problems more deeply along with the solution.

In this study, a roadmap for the development of halal logistics policies will be made using the road-mapping model approach and referring to SISLOGNAS key drivers. The roadmapping approach is the creation of a shared vision. The road-mapping process classifies future goals, and the path to achieving that goal. As a guideline for policy strategy also refers to Presidential Regulation 26 of 2012 concerning the National Logistics System Blueprint, in carrying out the National Logistics development strategy based on six key drivers including Main Commodities, Transportation Infrastructure, Logistics Service Providers and Providers, Human Resources, Information and Communication Technology and Regulations and Policies. Therefore, in formulating government policies and facilities in supporting halal logistics, it can refer to these six key drivers. 


\section{Research Methodology}

The research method is conducted by reviewing existing policies and then making policy recommendations through a roadmaping strategy.

The first stage is SWOT analysis in determining indicators based on market potential, products and technology analysis. The next step is to design a road map including time and determination of available resources to achieve the objectives.

In this paper we propose a roadmap to support the development of new business models, their implementation and evaluation. For the roadmap, a set of tools is proposed to support each stage from the design of the business model to its evaluation.

\section{Result And Discussion}

\section{A. Identification of the Cause and Effect Method}

\section{Equipment}

\section{IT System}

The rapid progress of information technology and the internet certainly has a significant impact on the system changes to various sectors in the world, including in the industrial and logistics sectors. In the industrial and logistics sectors, the most felt impact of this IT progress is the increasing speed and accuracy in each process.

Internet-based applications and web services are also widely available to support the functions in the logistics service industry business processes, for example: for transporting and storing cargo in warehouses with the help of information-based services such as transportation route information, highway condition information, claim management, vehicle transportation mode tracking, calculation of transportation cost predictions to reporting (Pokharel, 2005).

Related to halal logistics, According to Tieman (2013) there are three basic halal logistics, including: direct contact with illicit products, risk of contamination, and perceptions of Muslim consumers. These three things are important to ensure the integrity of the halal products produced. By utilizing the IT system above, the level of accuracy to avoid direct contact with illicit products and the risk of contamination can be minimized.

\section{Method}

Logistics Infromatization Tracking is a method for defining and tracking the exact position of goods both during the production, shipping and storage processes in the warehouse. Referring to the previous Tiemen (2013) statement, this method is believed to be able to increase the posture of implementing halal logistics in Indonesia.

\section{People}

\section{a. Consumer}

According to the Central Statistics Agency (BPS) the population of Indonesian Muslims reaches 207 million Muslims or 87.18\% of the Indonesian population (BPS 2010). So with such a large market share of halal products, the need for halal products in the market is very large. Based on a survey conducted by the Indonesian Majlis Ulama (MUI) research team, it was revealed that the level of Indonesian people's awareness of halal products increased very 
significantly. If in 2009 the level of public awareness of product halalness was only around $70 \%$, by the end of 2010 that number had jumped to around $92.2 \%$, which meant that this potential should have made Indonesia as a world-class halal producer (Syahruddin 2014).

\section{b. Producer}

In the past five years, industrial growth carrying the halal concept in Indonesia has reached 40\%, consisting of clothing, food, bottles, cosmetics and financial sharia (Mix, 2017). The Institute for Food, Drug and Cosmetic Studies of the Indonesian Ulema Council (LPPOM MUI) as the only institution authorized to provide halal certificates until 2014 as many as 26,979 out of 8,636 companies with 53,383 certified products from 231,851 products circulating (Ministry of Religion, 2015).

The State of The Global Islamic Economy report from 2016 to 2017 published by Thomson Reuters ranked Indonesia first for consumers of halal food products, which amounted to $\$ 154.9$ billion. However, the Indonesian government has not been able to maximize the market potential because Indonesia is still ranked 10th in the category of halal food producers.

\section{c. Logistics Service Provider}

From the volume of logistics spread in Indonesia, 55\% is still handled by the industry and has not outsourced, which is an opportunity for supply chain companies. But from around 12,500 supply chain companies there are only a small number of companies that specifically have halal licenses (Yukki N Hanafi, ALFI, 2016).

\section{Environment}

\section{a. Location of halal industry}

The Ministry of Industry has been planning for the establishment of a halal industrial area which is targeted to be completed before 2020. This is in response to the increasing demand for halal products in the world. Halal industrial zones are industrial estates in which all industries apply or comply with Islamic standards ranging from upstream to downstream. This Halal Industrial Area will be selected in the Java region because there is already an industrial area for the consumer goods sector. As for its management, the government will submit to one business actor who has known good halal production standards

\section{b. Bonded Logistics Center (PLB)}

The latest policy as an instrument for reforming the National Logistics System is the establishment of a Bonded Logistics Center (PLB) which is contained by Government Regulation Number 85 of 2015 concerning Amendments to Government Regulation Number 32 of 2009 concerning Bonded Stockpiling Sites. Through this policy the Government seeks to provide various facilities and incentives to the national business community.

The existence of a Logistics Center Bonded (PLB) has been responded to well by the business community because it is considered to have been able to provide assurance for the growth of the industrial world through various incentive offers, especially tax related. This is supported by the rapid level of achievement of the number of Bonded Logistics Centers (PLB) which in the first year only amounted to 11 rapidly increasing to reach 76 at the end of 2017 which spread from Lhokseumawe in Aceh to Sorong in West Papua. This increase in numbers indicates that the existence of the Bonded Logistics Center (PLB) contributes positively, 
especially to the flow of supply of raw or semi-finished materials needed by the national industry.

Associated with halal logistics, the increasing number of companies incorporated with PLB has made warehousing service providers in Indonesia increase. Thus, separating halal and unclean goods when the storage process becomes more feasible.

\section{B. SWOT Analysis}

\section{Strength}

a. Halal logistics goals are to ensure product halal along the flow in the supply chain. Halal logistics is developing because the level of consumer awareness is getting higher, in addition to product halalness, the halal logistics process or supply chain (Setijadi, 2016).

b. According to Antonius (2016), consumers in the world currently want cosmetics to pharmaceutical products that are halal certified, not just food.

c. The halalness of a product is not only viewed from how the product is produced, but also must be seen from how the product is processed, including in this case the process of handling the flow of materials / products such as transportation, storage and so on. So, halal not only concerns the product content, but also relates to halal and halal supply chain logistics systems

d. The halal logistics movement has been initiated by the President Director of PT Pos Indonesia (Persero) which supports halal logistics (Bisnis Indonesia, December 15, 2015), and PT Pelabuhan Indonesia II (Persero) through its subsidiary IPC Logistics Services will work on the first halal port in Indonesia (Kompas, October 26, 2015).

\section{Weekness}

a. Indonesia does not yet have halal standards for logistics matters to consumers (www.gomuslim.co.id).

b. There are no supply chain companies in Indonesia that have halal licenses (Alhafidz, 2016).

c. Not many industries in Indonesia are interested in this business with halal standardization (Antonius, 2016).

d. The lack of regulation of halal guarantee systems and systems and the absence of tools / software that ensure halality (Vanany, 2017).

e. There are not many halal logistics experts, therefore halal logistics training is important for employees involved in handling halal products (Jaafar et al. 2013).

\section{Oportunity}

Indonesia is a country with the largest percentage of Muslim population in the world, around $12.5 \%$ of the world population or as much as $88 \%$ of the approximately 250 million Indonesian population (Lawi, 2016).

\section{Threat}

a. Halal supply chain implementation requires more coordination and collaboration than halal products. Halal supply chains must be understood by actors in the supply chain. The 
lagging understanding and implementation of halal supply chains has the potential to weaken competitiveness (Setijadi, 2016).

b. According to Simatupang (2016) the challenges of Indonesian Halal Logistics include: the development of halal industries; Halal park operator; Halal producers; Warehousing; Technology; Halal Logistics Services Business Development; Tariff and non-tariff barriers; Market niche development; Willingness to pay from customers; and Customer Education.

c. The difficulty of managing to ensure halal in the supply chain perspective is because the halal food chain becomes longer and more complex, from producers to consumers (Vanany, 2017).

d. Malaysian pioneering in halal supply chain can be a threat to Indonesia, including the food industry and Indonesian logistics service providers (Setijadi, 2016).

e. About 90 percent of halal products are produced in non-Muslim countries. The halal and halal logistics status of a product is uncertain (Jaafar et al. 2013).

\section{Roadmap Halal logistics development policy strategy with SISLOGNAS six key} drivers

\section{Regulation}

In order to be able to implement a halal logistics system in Indonesia, regulation from the government is a must. This regulation can be a law that requires logistical agents to shift existing systems (in this case especially when the process of shipping and stockpiling) becomes a system that supports halal logistics, thus the halal logistics system is no longer based solely on consciousness but becomes a provision that must be followed by every logistics agent. In addition, the government can also establish an institution in charge of measurement, where the raw goods which should have a halal certificate will be checked for halal, then checked again when the goods are ready to be distributed to consumers to ensure the goods remain in the market conditions during upstream to the final consumer.

\section{Information and Communication Technology (ITC)}

Currently the logistics information system has become increasingly popular, used by both industry players and companies engaged in logistics. The problem, LIS itself does not have a special function to maintain the halalness of a product. In order for the halal logistics system to work properly, it is necessary to add a separate tracking system to SIL, for example, with its own barcode code to show whether the goods are halal and not, or even items that are easily contaminated or not. With this tracking system, the separation between halal and illicit goods will be easily separated both during the shipping and storage process, which means that the risk of changes in the halal value of an item will be minimized which of course strongly supports the implementation of halal logistics systems in Indonesia.

\section{Human Resources}

Higher education acts as a center for study and halal logistics research and HR competency development and halal logistics organizations. Halal logistics research is directed at developing logistics systems, infrastructure, technology, and halal logistics business processes. Research is also directed towards the development of halal logistics markets, both domestic and international market segments. 
Meanwhile, universities also have a role in building human resource competencies that will struggle in the field of logistics. Thus, so that the halal logistics system can run well, every university that has a department or logistics study program needs to include this halal logistics related learning into the lecture curriculum. Thus, it is expected that HR who will later be involved in logistics have competent competencies in halal logistics

\section{Logistics agents and Logistics Service Providers}

The development of the halal market requires increased efficiency in the market to offset this growth. One approach that can be used is supply chain management (SCM) (Noordin, Noor, \& Samicho, 2014). SCM can be used to increase productivity and profitability of the halal market (Noordin et al, 2014). Strategic and systemic coordination of business functions in a company is the key to the successful implementation of SCM in the company. Traditional SCM can be defined as the process of converting raw materials into finished goods and then distributing them to end consumers (Manzouri, Ab-Rahman, Zain, \& Jamsari, 2014). In the increasingly rapid development of industry, especially the development of the halal industry, traditional SCMs are considered not sufficient to accommodate market needs. Therefore, SCM develops according to industry needs to become halal supply chain.

Halal supply chain can be defined as the integration of processes and business activities from raw materials to end consumers (from farm to plate) (Omar \& Jaafar, 2011). So the difference between SCM and halal supply chain is the goal. Supply chain management (SCM) is applied in companies so companies can reduce production costs. On the other hand, halal supply chain is used by companies with the aim of maintaining and maintaining product halalty (Gillani et al, 2016). The halal integrity of products (halal integrity) will be one of the competitive advantages for producers to be able to compete with other producers in the same industry. The following are examples of halal supply chain images to be able to maintain product halalness. Only halal species can be bred and halal species do not consume unclean feed (Soon, Chandia, \& Regenstein, 2017).

To encourage and facilitate the implementation of halal supply chain in Indonesia, Setijadi (2016) argues, the strong role of the Indonesian Government is needed, in this case including preparing facilities and infrastructure in implementing halal and halal supply chain logistics, which include logistics centers, warehousing airports, freight terminals, port, goods terminal, warehousing and so on. Likewise according to Zaroni (2016), the development of halal logistics in Indonesia needs to be encouraged and directed towards halal logistics management in an integrated supply chain management system.

According to him, the blueprint for halal logistics development in Indonesia needs to be compiled immediately, as a halal logistics development master plan in Indonesia. Blue map is needed for the concept of the halal product industry supply chain in Indonesia (www.gomuslim.co.id). On the other hand, Hutauruk (2016) said that goods truckers said the discourse on halal supply chain implementation would be ideal if the government had a transparent and clear certification component.

\section{Infrastruktur dan Transportasi}

If we look at Indonesia's geographical conditions and its population distribution, halal hub ports are one of the important facilities in the implementation of halal supply chains in Indonesia. Halal hub port will make the processes needed in halal supply chain implementation effective and efficient (Setijadi, 2016). In order to realize the halal hub port, on 2 August 2016 PT Pelabuhan Indonesia II (Persero) / IPC with PT Jakarta Industrial Estate Pulogadung (JIEP) signed a memorandum of understanding (MoU) on the preparation of a 
joint study on the development and operation of integrated halal logistics areas JIEP area. This agreement aims to prepare everything related to halal international hubs in the JIEP region. Halal hub is a transit area for products originating from non-Muslim countries, with the aim to Muslim countries such as Indonesia (Lestari and Hakim, 2016).

PT Multi Terminal Indonesia, often called IPC logistics, is a subsidiary of PT Pelabuhan Indonesia II (IPC). PT Multi Terminal Indonesia operates a Halal Logistics \& Cold Storage Unit which covers the handling of goods, storage and distribution of halal products (www.ipclogistics.co.id). PT Multi Terminal Indonesia has partnered with LPPOM MUI in order to implement a halal port or halal hub port in the Tanjung Priok Port of North Jakarta. The collaboration was confirmed through the signing of a memorandum of understanding between the two institutions (Hutauruk, 2016). On the other hand, PT Pos Indonesia as one of the Government Owned Enterprises (SOEs) also supports the development of the Halal Movement in Indonesia. The one done is by preparing a generation that has competence in the field of halal. (Firmansyah, 2015).

\section{Main Commodity}

Logistics can be defined as a process of planning, implementation, and control related to the process of storing goods and services in order to meet the needs of customers. The main objective of logistics is to ensure that consumers can enjoy, use, or consume products at the right time and amount, as needed, and in good condition (Talib \& Hamid, 2013). So it can be concluded that logistics management includes a variety of activities, including: transportation, storage and warehousing, inventory management, service to consumers, and so on.

All halal products must follow sharia law, including the logistics process. Therefore, there is a need for a logistics process that applies sharia principles in its implementation. The main principle of halal logistics is ensuring the separation between halal and non-halal products. From all supply chains, logistics service providers play an important role in ensuring that raw materials, raw materials, packaging, storage and transportation of halal products have been carried out properly so that they are not contaminated with non-halal products (Soon et al, 2017). According to Tieman (2013) there are three basic halal logistics to ensure the integrity of the halal products produced, including: direct contact with illicit products, risk of contamination, and perceptions of Muslim consumers. Potential products that can be used as a focus for mining include:

- Halal Food Products

- Cosmetics and Halal Medicines

- Halal Logistics

- Halal tourism

- Muslim Fashion

- Halal Media and Recreation

- Islamic finance

\section{Indicator of the Roadmap for Halal Logistics Development Strategy}

In accordance with the main criteria for guaranteeing halal products, referring to the law guaranteeing halal products and the main indicators of the National Logistics System, several indicators can be used in preparing the Roadmap for Halal Logistics Development Policy Strategy roadmap. The following indicators are used: 


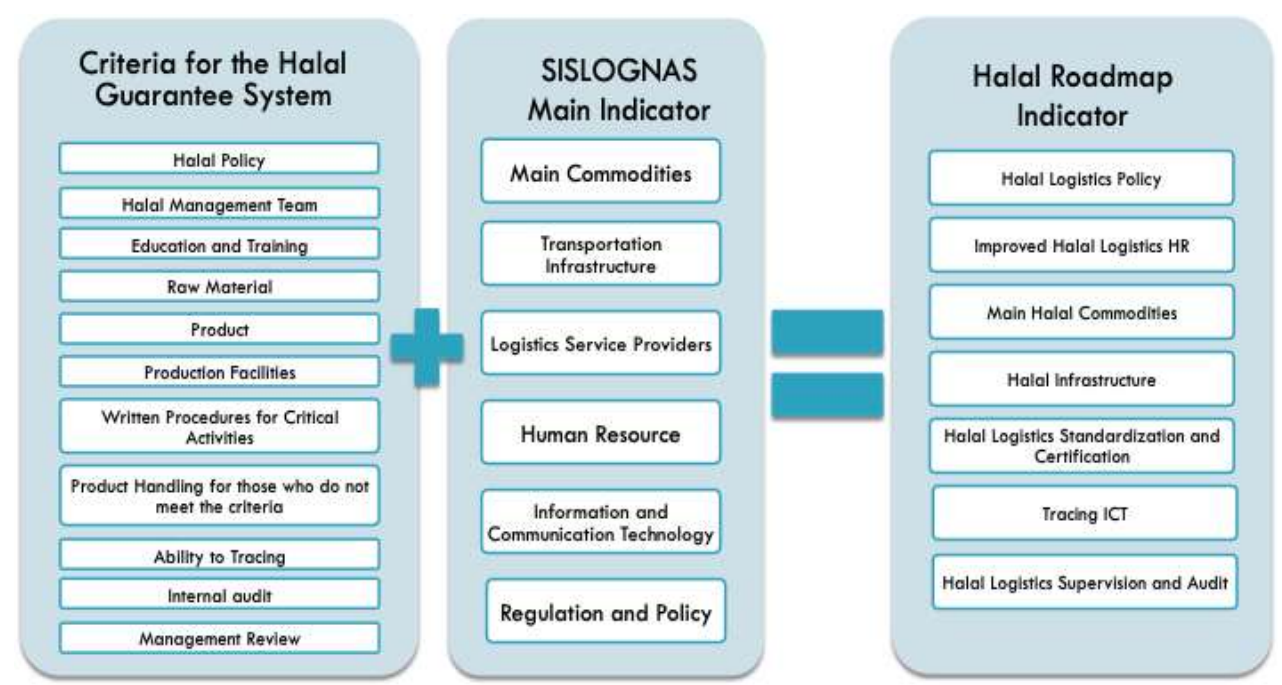

Figure 1. Indicator of the Roadmap for Halal Logistics Development Policy Strategy

\section{E. Implementation Phase of the Halal Logostics Development Policy Strategy Roadmap}

Halal Logistics Development Policy through the Roadmap The Halal Logistics Development Policy Strategy can be described as follows:

Phase II

2028-2031

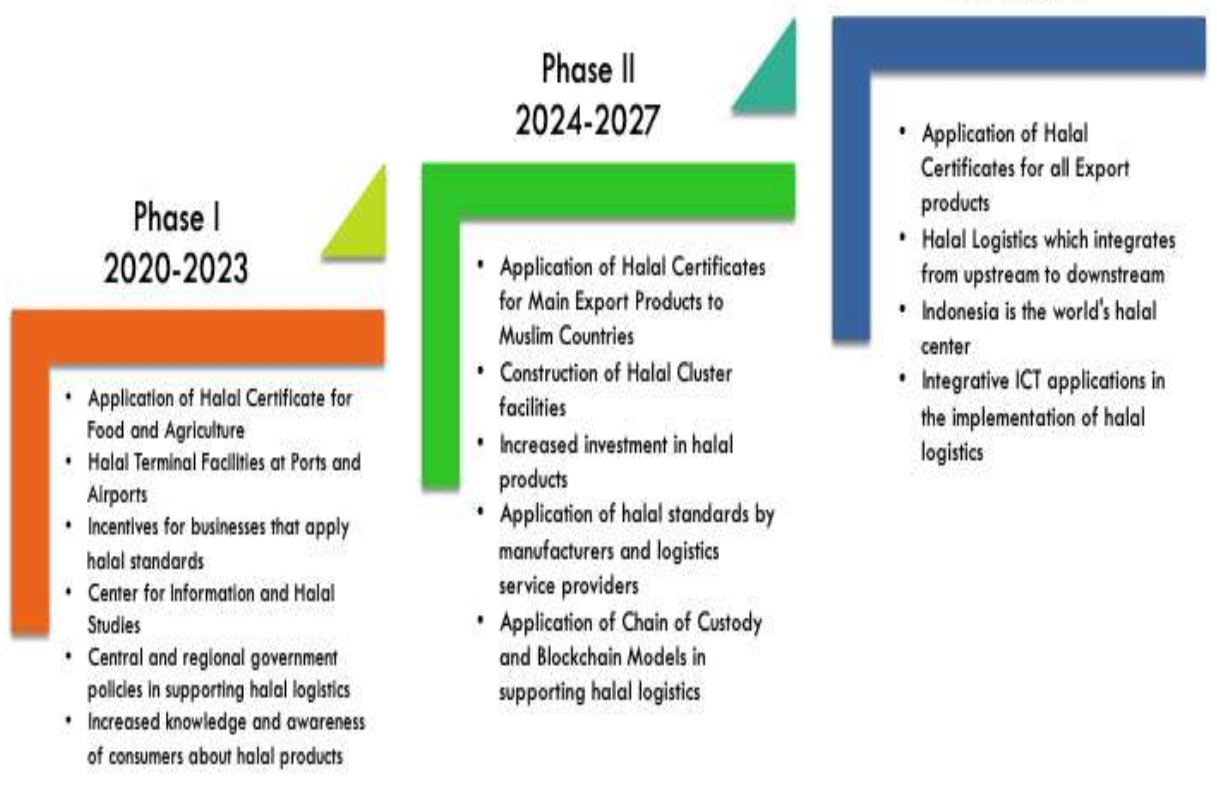

Figure 2. Implementation Phase of the Halal Logostics Development Policy Strategy Roadmap 


\section{Conclusion}

From the description above it can be concluded, halal logistics is the application of the principles of halalan toyyiban throughout supply chain activities. All activities ranging from sources of supply, storage, transportation, manufacturing, handling, and distribution must comply with the concept of halalan toyyiban. Halal logistics goals are to ensure product halal along the flow in the supply chain. Halal logistics is developing because of the higher level of consumer awareness, in addition to product halalness, it is also the halal of logistics and supply chain processes.

Halal logistics is important in Indonesia and the roadmap can be used in Indonesia in developing a national halal logistics system. The government's strong role in encouraging and facilitating the implementation of halal logistics is needed in dealing with problems and challenges. Along with this, researchers and academics have had the time to conduct research in the field of halal logistics.

\section{Reference}

[1]. Syahruddin. 2014. Potential Progress of People Through Halal Products. http://majalahgontor.net/potensi-kemajuan-umat-melalui-produk-halal/. Accessed December 14, 2018.

[2]. Mix Editor. 2017. The Rise of the Indonesian Muslim Market. Mix: Marketing \& Communication 06/XIV 20 Juni 2017 - 18 Juli 2017.

[3]. Ministry of Religion. 2015. LPPOM MUI Halal Certification Data. Ministry of Religion, Directorate General of Guidance for Islamic Communities.

[4]. Thomson Reuters. 2016. State of the Global Islamic Economic Report 2016/2017. www.kemenperin.go.id

[5]. Pokharel, S. 2005. Perception on information and communication technology: perspective in logistics, The Journal of Enterprise Information Management, Vol. 18 No. 2, pp. 136-49

[6]. Tieman, M. 2013. Establishing The Principles In Halal Logistics. Journal of Emerging Economies and Islamic Research, 1 (1).

[7]. Talib M.S.A. \& Hamid A.B.A. (2014). Halal Logistics in Malaysia: A SWOT Analysis. Journal of Islamic Marketing Vol.5 No.3.

[8]. Jaafar H.S., Faisol N., Rahman F.A., dan Muhammad A. 2016. Halal Logistics Versus Halal Supply Chain: A Preliminary Insight. Springer Science \& Business Media Singapore.

[9]. AlHafiz M.P. 2016. Halal licenses have not touched the logistics chain. Retrieved December 26, 2018, available at http://marketeers.com/lisensi-halal-belummenyentuh-rantai-logistik/

[10].Antonius S. 2016. Halal Supply Chain Masih Sebatas Awareness di Indonesia. https://www.truckmagz.com/halalsupply-chain-masih-sebatas-awareness-di-indonesia/ Accessed on December 26, 2018.

[11].Setijadi. 2016. Halal Hub Port. . http://supplychainindonesia.com/new/halal-hub-port/ Accessed on December 26, 2018.

[12]. Vanany I. 2017. Halal Traceability System pada Supply Chain Makanan. SCL Note Magazine Edition I, Mid Semester I (March) 2017.

[13].Jaafar H.S., Omar E.N., Osman M.R., dan Faisol N. 2013. The Concept of Halal Logistics - An Insight. Paper Presented at ICLT, Kyoto Japan.

[14].Ahmad N. \& Shariff S.M. 2016. Supply Chain Management: Sertu Cleansing for Halal Logistics Integrity. Procedia Economics and Finance 37 418-425.

[15].Farrukh, C., Phaal, R., dan Probert, D (2003) 'Technology roadmapping-linking technology resource into business planning'. International Journal of Technology Management.

[16].Law Number 33 of 2014 concerning Guaranteed Halal Products

[17].Nadler, Gerald., and Hibino, Shozo., (1994) 'Breakthrough Thinking, Revised 2nd Edition: The 
Seven Priciples of Creative Problem Solving' Prima Publishing \& Communications.

[18].Presidential Regulation of the Republic of Indonesia Number 26 of 2012 concerning Blueprint of National Logistics System Development.

[19].Tieman, M. (2011). The application of Halal in supply chain management: in-depth interviews. Journal of Islamic Marketing, 2(2), 186 - 195.

[20].Tieman, M. (2015) "Halal clusters", Journal of Islamic Marketing, Vol. 6 Issue: 1, pp.2-21,

[21].Zulfakara, MH., Anuarb, MM., dan Talib, MSA (2012) 'Conceptual Framework on Halal Food Supply Chain Integrity Enhancement '. International Halal Conference, Kuala Lumpur. 